Accepted Author Manuscript of

Breitner D, Osán J, Fábián M, Zagyvai P, Szabó C, Dähn R, Marques Fernandes M, Sajó I, Máthé Z, Török S. Environmental Earth Sciences 73 (2015) 209-219

The final publication is available at Springer via http://dx.doi.org/10.1007/s12665-014-3413-4

\title{
Characteristics of uranium uptake of Boda Claystone Formation as the candidate host rock of high level radioactive waste repository in Hungary
}

Dániel Breitner ${ }^{1}$, János Osán ${ }^{1 *}$, Margit Fábián ${ }^{1}$, Péter Zagyvai ${ }^{1}$, Csaba Szabó ${ }^{2}$, Rainer Dähn ${ }^{3}$, Maria Marques Fernandes ${ }^{3}$, István E. Sajó ${ }^{4}$, Zoltán Máthé ${ }^{5}$, Szabina Török ${ }^{1}$

${ }^{1}$ Centre for Energy Research, Hungarian Academy of Sciences, P.O. Box 49, H-1525 Budapest, Hungary

${ }^{2}$ Lithosphere Fluid Research Lab, Eötvös University, Pázmány Péter sétány 1/c, H-1117, Budapest, Hungary

${ }^{3}$ Laboratory for Waste Management (LES), Paul Scherrer Institute, 5232 Villigen PSI, Switzerland

${ }^{4}$ Research Centre for Natural Sciences, Hungarian Academy of Sciences, Pusztaszeri út 59-67, H1025, Budapest, Hungary

${ }^{5}$ Mecsekérc Plc. Esztergár utca 19, H-7633, Pécs, Hungary

*Corresponding author: e-mail: janos.osan@energia.mta.hu

\begin{abstract}
In Hungary two geological sites of the Boda Claystone Formation (BCF) located in the W-Mecsek Mountains (South Hungary) have been selected for the study of potential host rocks for high level radioactive waste (HLW), Gorica (G) Block and W-Mecsek Anticline (WMA) Block. The aim of the study was to obtain information on the uranium uptake characteristics of both sites.

Our results revealed that in the sample, taken from WMA Block, where dolomites have ankerite rims and U-bearing rings, newly formed $\mathrm{FeOOH}$ precipitations were observed, which partly replaced the ankerite at near neutral $\mathrm{pH}(6.8) . \mathrm{UO}_{2}{ }^{2+}$ ions were adsorbed easily due to the enhanced specific surface area and high adsorption capacity of $\mathrm{FeOOH}$ formed from the dissolution of ankerite. The oxidation of $\mathrm{Fe}^{2+}$ leads to the formation of $\mathrm{FeOOH}$ parallel to partial reduction of $\mathrm{U}^{6+}$ to $\mathrm{U}^{4+} .75 \%$ of uranium was taken up by clay minerals and $25 \%$ by $\mathrm{FeOOH}$ although the ankerite concentration is as low as $6 \%$ in WMA Block of BCF. In G Block, the argillaceous matrix was found to be mainly responsible for the $\mathrm{UO}_{2}{ }^{2+}$ uptake. The study demonstrated that the $\mathrm{U}$ retention capacity of different BCF locations was significantly influenced by the mineralogy of these sites.

Keywords: Boda Claystone Formation, uranium uptake, ankerite, FeOOH, nuclear waste repository
\end{abstract}

\section{Introduction}

In order to confirm the feasibility of a potential high level radioactive waste (HLW) repository site (Schwartz 2009; Andersson et al. 2013), the retention of uranium has superior significance, provided that it is released from the conditioned waste. In Hungary, the investigation of potential host rock for HLW disposal started by studying Boda Claystone Formation (BCF). The national investigations pointed out that BCF displayed exceptional features for HLW disposal and further detailed research was suggested. On BCF samples, in addition to the geological studies, numerous sorption and migration tests have been performed such as in situ diffusion and break through tests of ${ }^{85} \mathrm{Sr},{ }^{137} \mathrm{Cs}$, ${ }^{60} \mathrm{Co},{ }^{14} \mathrm{C},{ }^{125} \mathrm{I},{ }^{99} \mathrm{Tc},{ }^{235 / 238} \mathrm{U},{ }^{232} \mathrm{Th},{ }^{241} \mathrm{Am}$ and ${ }^{239} \mathrm{Pu}$ (Mell 2006ab; Guczi and Szabó 1995, 1996 and 1997; Szabó et al. 2004).

Uptake mechanisms of uranium have been studied on materials of the engineered barriers of a future repository installation such as hardened cement paste (Wieland et al. 2010; Gaona et al. 2012) and bentonite (Meleshyn et al. 2009; Bachmaf and Merkel 2011). The retention of $\mathrm{UO}_{2}{ }^{2+}$ by different argillaceous host rocks was also studied for Opalinus Clay, Switzerland, as well as Callovo-Oxfordian Clay, France (Bradbury and Baeyens 2011; Joseph et al. 2011; Hartmann et al. 2008), mostly using wet chemistry batch experiments involving bulk samples and sorption modelling. However, the 
mineralogical and geochemical processes of the uptake onto different host rocks are hardly understood. Although clay minerals were found to play an important role in the retention of uranium, other mineral phases such as quartz and especially iron oxy-hydroxides cannot be excluded as effective adsorbents of $\mathrm{UO}_{2}{ }^{2+}$ (Green-Pedersen and Pind 2000; Joseph et al. 2011; Nair et al. 2014). Furthermore, Zheng et al. (2003) pointed out that ferrihydrites in soils in oxidizing conditions have much larger specific sorption capacity for $\mathrm{UO}_{2}{ }^{2+}$ than clays. For this reason it is important to identify, which mineral phases are responsible for the $\mathrm{UO}_{2}{ }^{2+}$ uptake on the microscale, complementing the wet chemistry studies. The spatial distribution of uranium was successfully studied on thin sections using synchrotron-radiation microbeam X-ray fluorescence (micro-XRF) in investigating rocks from a natural analogue site for radioactive waste disposal (Denecke et al. 2005) and for cementitious materials after diffusion experiments (Wieland et al. 2010). Although information concerning spatial heterogeneity in uptake mechanism would be essential, studies involving petrographic thin sections after sorption experiments are very limited and dealing only with other elements such as Np (e.g. Fröhlich et al. 2012). Investigations with high sensitivity analytical methods such as micro-XRF are missing for BCF.

The present study deals with the identification of mineral phases responsible for the uranium uptake in micrometer scale in two mineralogically different blocks, i.e. Gorica (G) Block and W-Mecsek Anticline (WMA) Block of BCF. For each block a representative drilling core section was selected for the present research based on detailed study on all available cores from the existing boreholes. The major objective is to understand the geochemical processes, which affect the retardation capacity of BCF. The study aims to identify whether the two blocks have different behaviour in uranium uptake that could influence their suitability for host rock of HLW repository.

\section{Geological background}

The Upper Permian sedimentary sequence of the BCF is located in W-Mecsek Mountains, southern Transdanubia (South Hungary) (Fig. 1). BCF is known in an area of $150 \mathrm{~km}^{2}$ of which $15 \mathrm{~km}^{2}$ can be found on the surface (Fig. 1). This formation has been selected for future HLW repository due to its low porosity, appropriate hydraulic conductivity and absence of organic residues (Boisson 2005).

Two distribution areas of BCF are known, the perianticlinal structure of the WMA Block and the G Block. These sites have been selected as the most appropriate candidates for host rock of the repository. Outcrop of BCF at G Block is not known and only one borehole (Ib-4) recovered the complete sequence of BCF (approx. $200 \mathrm{~m}$ ). On the basis of the deep drillings, total thickness of BCF is estimated to be about 700-900 m in WMA Block, whereas its thickness is smaller about $350 \mathrm{~m}$ in the G Block. The sediments of the BCF are dominantly red and reddish brown in colour, reflecting the dominantly oxidizing nature of the depositional and early diagenetic environments (Jámbor 1964; Barabás and Barabás-Stuhl 1998; Máthé 1998; Árkai et al. 2000; Varga et al. 2005; Lázár and Máthé 2012). The BCF was deposited in a shallow-water salt lake environment surrounded by dry to saline mudflat, under semi-arid to arid climatic conditions (Barabás and Barabás-Stuhl 1998; Máthé 1998; Árkai et al. 2000; Varga et al. 2005; Máthé and Varga 2012) (Fig. 2).

In WMA Block the main rock-forming minerals of the $\mathrm{BCF}$ are clay minerals (mainly illite and chlorite), authigenic albite, detrital quartz, carbonate minerals (calcite and dolomite) and hematite (Máthé 1998; Árkai et al. 2000; Varga et al. 2005; Varga et al. 2006). In addition to the major minerals, barite, anhydrite, authigenic K-feldspar and detrital constituents were also identified in trace amounts. The authigenic albite is present as albite cement, albite and carbonate-lined disseminated irregular white voids and albite replacement of detrital feldspars in sandstone beds (Máthé 1998; Árkai et al. 2000; Varga et al. 2006). In addition to albite, carbonate minerals (fine-grained calcite and euhedral-rhombohedral dolomite) and authigenic K-feldspar are present in these voids. On the basis of their morphology, these albite-, carbonate- and K-feldspar-lined voids are replacements of the previous halite crystals (Máthé and Varga 2012). The BCF recovered by borehole Ib-4 (G Block) differs in its mineralogical composition. This succession of BCF contains abundant analcime in addition to the above mentioned minerals (Sipos et al. 2010; Lázár and Máthé 2012). Similarly to the authigenic albite, the analcime is present as analcime cement and pore infillings. The dominant rock type of the formation is albitic claystone in the WMA Block and albite- and analcime-bearing claystone in the G Block (Konrád 2010). 


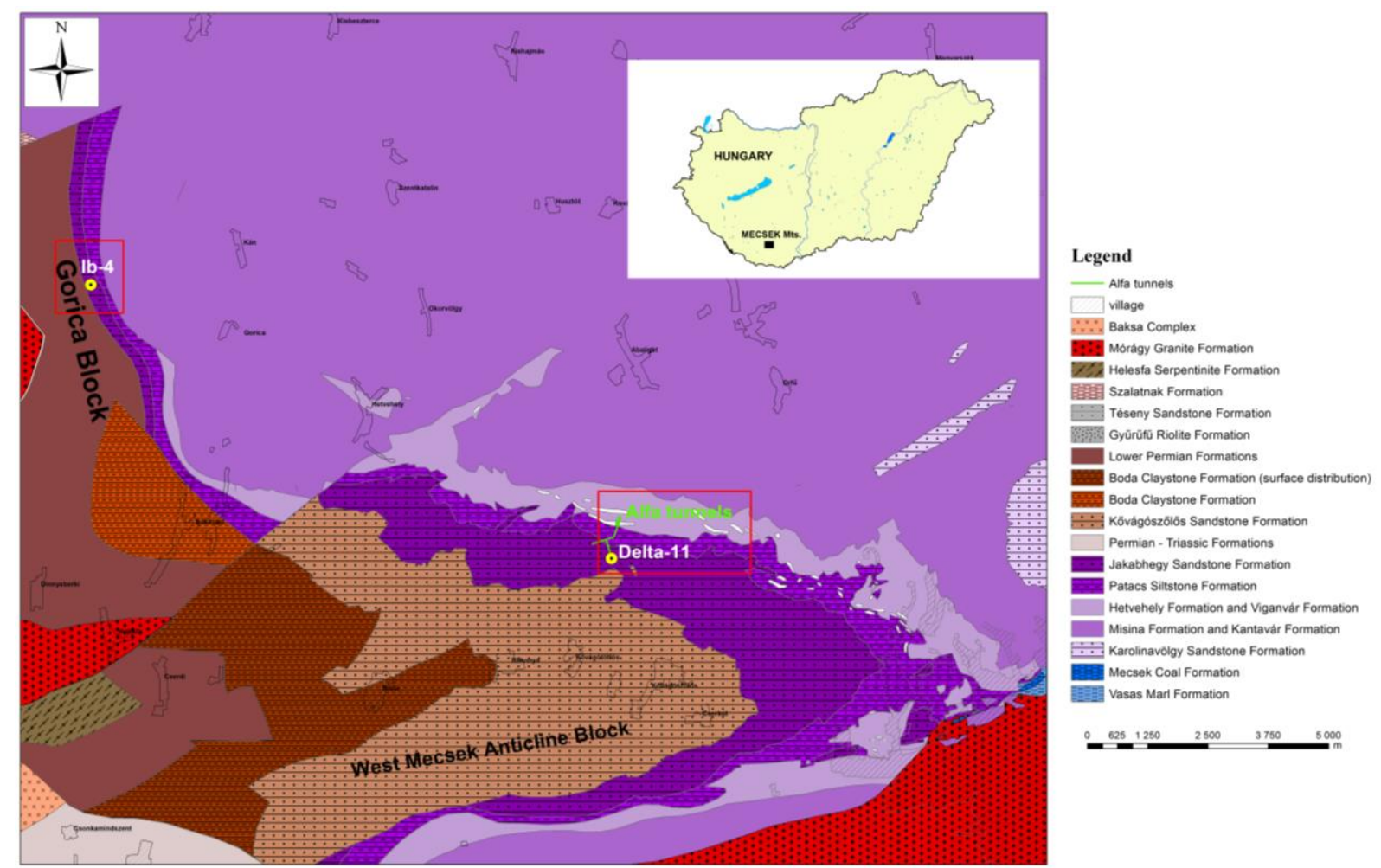

Fig. 1 Pre-Cenozoic geological map of Mecsek Mts and locations of studied objects marked by red rectangles (boreholes: Ib-4 and D-11 in the Alfa tunnels)

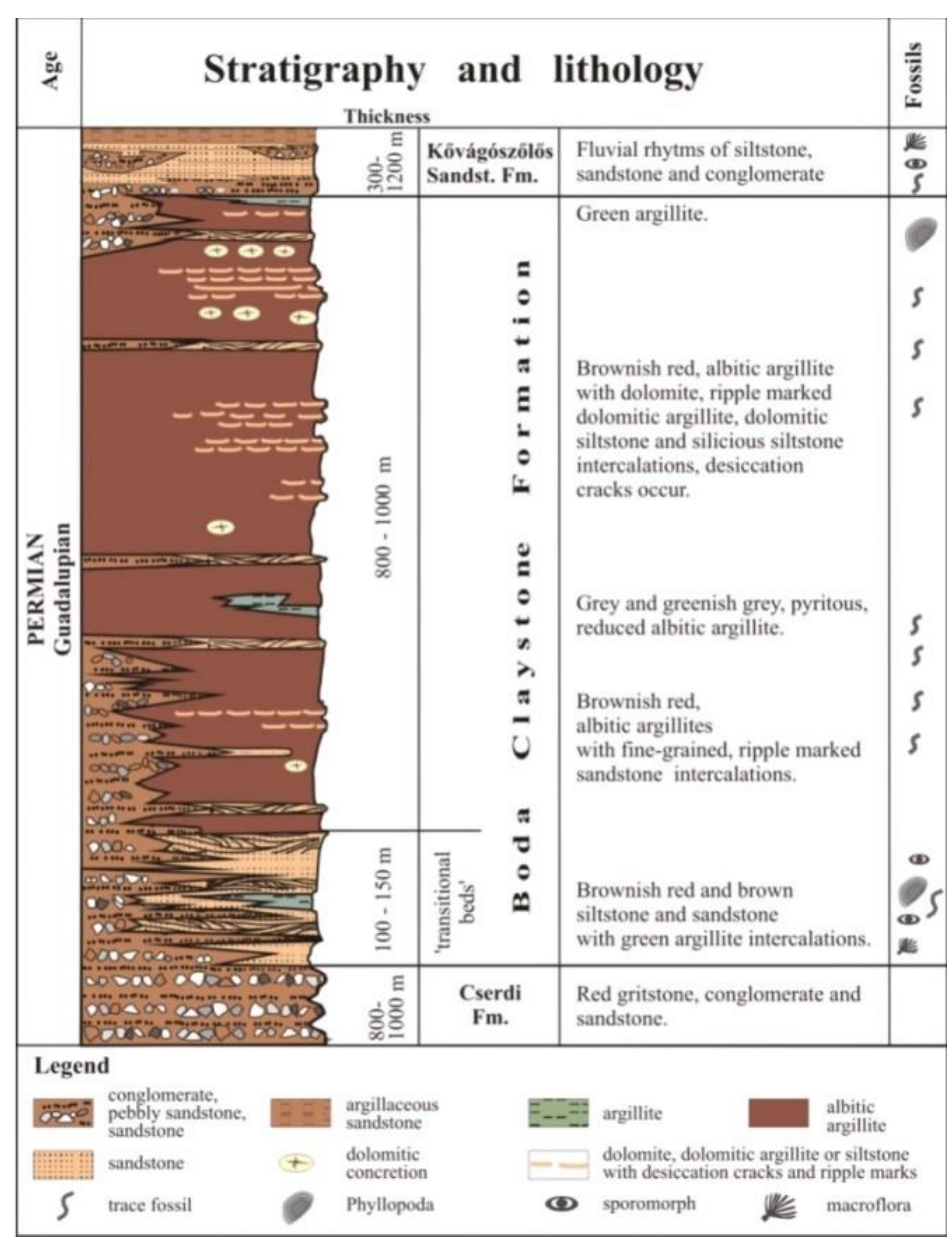

Fig. 2 Idealized lithologic column of Boda Claystone Formation (Lázár and Máthé 2012) 


\section{Materials and methods \\ Samples}

Based on their depth and representativeness for $\mathrm{BCF}$, a ca. $20 \mathrm{~cm}$ long clay rich core sample of the two boreholes, IB-4 at a depth of 540 m, representing Gorica Block, and D-11 from the Alfa tunnels (Fig. 1) at a depth of ca. $1000 \mathrm{~m}$, representing W-Mecsek Anticline Block, were selected for detailed sorption study.

The results of the powder X-ray diffraction (XRD) analyses of the two selected samples are presented in Table 1. The results revealed that BCF in WMA Block (sample D-11) has lower illite and quartz content than those in the G Block (sample Ib-4). Sample D-11 has high albite content and contains ankerite, too, whereas sample Ib-4 has lower albite content, and contains analcime however no ankerite was identified.

The albite and ankerite are present in the clayey matrix, and as fracture and vug infilling (Fig. 3). Euhedral dolomites are such grains connected to or in the fractures. In sample D-11 dolomites are zoned and have ankerite rims (Fig. 3 left). Based on the previous electron probe microanalysis (EPMA) results, calcites and dolomites contain low amount of $\mathrm{Mn}$ and $\mathrm{Fe}(<1 \mathrm{wt} . \% \mathrm{MnO}$ and $\mathrm{FeO}$ in calcite and 0.3 wt. $\% \mathrm{FeO}$ and ca. 2 wt. \% MnO in dolomite) (Németh 2011). The pore water composition is in accordance with the shallow-water salt lake environment of the deposition of BCF, the chemical composition corresponding to the Ib-4 sample is shown in Table 2.

Table 1 Semi-quantitative mineral composition (wt. \%) of the bulk samples, measured by XRD

\begin{tabular}{llllllll}
\hline $\begin{array}{l}\text { Sample } \\
\text { (Depth) }\end{array}$ & $\begin{array}{l}\text { Illite } \\
\text { (wt. \%) }\end{array}$ & $\begin{array}{l}\text { Albite } \\
(\text { wt. \%) }\end{array}$ & $\begin{array}{l}\text { Analcime } \\
\text { (wt. \%) }\end{array}$ & $\begin{array}{l}\text { Quartz } \\
(\text { wt. \%) }\end{array}$ & $\begin{array}{l}\text { Calcite/dolomite } \\
\text { (wt. \%) }\end{array}$ & $\begin{array}{l}\text { Hematite } \\
\text { (wt. \%) }\end{array}$ & $\begin{array}{l}\text { Ankerite } \\
\text { (wt. \%) }\end{array}$ \\
\hline $\begin{array}{l}\text { D-11 } \\
\text { (Ca. 1000 m) }\end{array}$ & 38 & 45 & & 0.5 & 3 & 6 & 6 \\
$\begin{array}{l}\text { IB-4 } \\
(540 \mathrm{~m})\end{array}$ & 50 & 17 & 10 & 8 & 8 & 6 & 0 \\
\hline
\end{tabular}

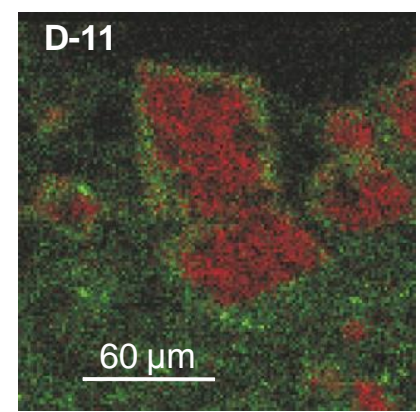

$\mathrm{Mg}$

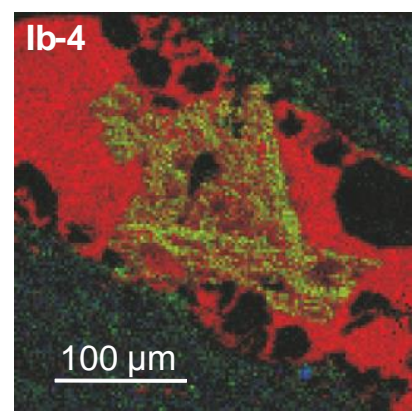

$\mathrm{Fe}$
$\mathrm{Ca}$

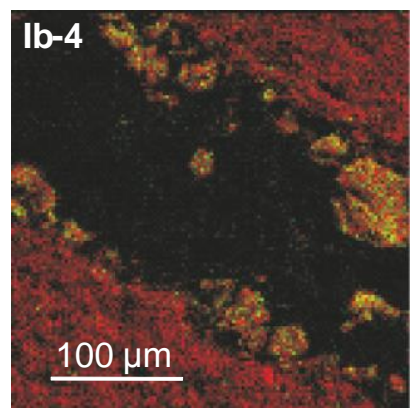

Al $\quad \mathrm{Na}$

Fig. $3 \mathrm{X}$-ray maps of $\mathrm{Mg}$ and $\mathrm{Fe}$ in a fracture filling zoned dolomite and calcite surrounded by argillaceous matrix in sample D-11 (WMA Block) and $\mathrm{Fe}, \mathrm{Ca}, \mathrm{Mg}, \mathrm{Al}$ and $\mathrm{Na}$ in a similar structural feature composed by calcite, dolomite, analcime and clayey matrix in sample Ib-4 (G Block)

Table 2 Chemical composition of BCF pore water from G Block (Ib-4)

\begin{tabular}{lll}
\hline Element & $\begin{array}{l}\text { Ib-4 } \\
(\mathrm{mol} / \mathrm{L})\end{array}$ & $\begin{array}{l}\text { (modelled) } \\
(\mathrm{mol} / \mathrm{L})\end{array}$ \\
\hline $\mathrm{Na}$ & $1.7 \times 10^{-2}$ & $1.7 \times 10^{-2}$ \\
$\mathrm{~K}$ & $1.8 \times 10^{-4}$ & $1.8 \times 10^{-4}$ \\
$\mathrm{Mg}$ & $2.4 \times 10^{-3}$ & $6.8 \times 10^{-5}$ \\
$\mathrm{Ca}$ & $3.1 \times 10^{-3}$ & $8.0 \times 10^{-5}$ \\
$\mathrm{Sr}$ & $1.5 \times 10^{-5}$ & $1.5 \times 10^{-6}$ \\
$\mathrm{Cl}$ & $2.3 \times 10^{-2}$ & $7.0 \times 10^{-4}$ \\
$\mathrm{SO}_{4}$ & $1.9 \times 10^{-3}$ & $1.9 \times 10^{-3}$ \\
$\mathrm{HCO}_{3} / \mathrm{CO}_{3}$ & $6.1 \times 10^{-4}$ & $1.3 \times 10^{-2}$ \\
$\mathrm{Ionic} \mathrm{strength}$ & $3.3 \times 10^{-2}$ & $1.9 \times 10^{-2}$ \\
$\mathrm{pH}$ & 8.0 & 8.7 \\
${ }_{\mathrm{H}} \mathrm{pH} / \mathrm{pCO}_{2}$ & & $8.2 / 10^{-2.3}$ bar \\
\hline
\end{tabular}




\section{Methods}

Four thin sections (ca. $50 \mu \mathrm{m}$ thick and $1 \mathrm{~cm}^{2}$ surface) were prepared from the two core samples by mounting them on high-purity $\mathrm{Si}$ wafers. Prior to the uptake experiments by immersing the thin sections in $\mathrm{UO}_{2}{ }^{2+}$ containing solutions, sorption modelling calculations were carried out to determine the maximum $\mathrm{UO}_{2}{ }^{2+}$ concentrations in the porewater and the corresponding uranium loadings on the BCF. The 2 Site Protolysis Non Electrostatic Surface Complexation and Cation Exchange (2SPNE SC/CE) sorption model (Bradbury and Baeyens, 2009) was used for these calculations. The procedure was to calculate the sorption on illite in the corresponding porewater with the surface complexation constants given in Bradbury and Baeyens (2009) and the results were then scaled to the $40 \mathrm{wt}$ \% clay content of BCF (see Table 1). These scooping calculations indicated that it was not possible without avoiding precipitation to obtain sufficiently high uranium loadings of ca. $50 \mu \mathrm{g} / \mathrm{g}$ on the BCF for the micro-XRF analyses. The procedure followed was to use a simple background electrolyte $(0.1 \mathrm{M}$ $\mathrm{NaCl})$ at a maximum $\mathrm{UO}_{2}{ }^{2+}$ concentration of $2 \times 10^{-6} \mathrm{M}$ at $\mathrm{pH}$ 6.8. Under these circumstances no precipitation should be occurring. However, it should be realized that dissolution of mineral phases cannot be avoided. To minimise these effects the thin sections were exposed for only 72-hour to the $\mathrm{UO}_{2}{ }^{2+}$ solution in $0.1 \mathrm{M} \mathrm{NaCl}$ at $\mathrm{pH} 6.8 . \mathrm{UO}_{2}{ }^{2+}$ was added to the $\mathrm{NaCl}$ solution in the form of ICP standard $\left(1000 \mu \mathrm{g} / \mathrm{L} \mathrm{U}\right.$ in $2 \% \mathrm{HNO}_{3}$ solution; Ultra Scientific, RI, USA) and the $\mathrm{pH}$ was set to 6.8 using $\mathrm{NaOH}$. The excess solution containing $\mathrm{UO}_{2}{ }^{2+}$ was removed from the sample surface using quick rinsing with distilled water. Under these conditions the samples could be prepared for the microscopic observations at sufficient high concentrations without precipitation.

The spatial distribution of $U$ on the treated thin sections was measured using micro-XRF at the FLUO beamline at the ANKA storage ring (Karlsruhe, Germany). Synchrotron radiation (SR) micro-XRF was applied for this study because this technique is sufficiently sensitive to examine trace amounts of uranium and has a high spatial resolution. In order to excite the $\mathrm{L}_{3}$ edge of uranium, white beam of a bending magnet was monochromatized to $17.5 \mathrm{keV}$ by a W/Si multilayer double monochromator. A compound refractive lens was employed for focusing a beam down to $3 \times 5 \mu \mathrm{m}^{2}$, resulting in a beam footprint of $3 \mu \mathrm{m}(\mathrm{V}) \times 8 \mu \mathrm{m}(\mathrm{H})$ on the sample due to the $45^{\circ} / 45^{\circ}$ geometry. The fluorescence yield was detected using an energy-dispersive silicon-drift detector. Micro-XRF maps were recorded from pre-selected areas of the samples such as clayey matrix and fracture- and vug-fillings, using a step size of $5 \mu \mathrm{m}$ and $10 \mathrm{~s}$ counting time per pixel. In order to resolve overlapping, characteristic X-ray peaks such as Rb-K $\alpha$ and U-L $\alpha$, full X-ray spectra were collected at each pixel and were processed using the AXIL software (Vekemans et al. 1994). Elemental distribution maps were recorded for the adsorbed element $(\mathrm{U})$ and for the major and minor elements of the rock (e.g. $\mathrm{K}, \mathrm{Ca}, \mathrm{Fe}, \mathrm{Rb}, \mathrm{Sr}$ ) using the resulting net characteristic $\mathrm{X}$-ray intensities. In addition to visualization of the spatial distributions, the elemental maps served as a basis for examination of inter-elemental correlations. A detection limit of as low as $10 \mu \mathrm{g} / \mathrm{g}$ could be obtained for uranium using a $10 \mathrm{~s}$ counting time, which can be expressed as $4 \times 10^{-5} \mathrm{~mol} / \mathrm{kg} \mathrm{U}$ sorbed, allowing investigation of the spatial distribution of the sorbed uranium at the microscale.

The proportion of phases having different uranium retention capacity was calculated by analysing the distribution of U-L $\alpha$ intensities $(I)$ over the areas scanned by micro-XRF. If only a single phase is responsible for the uptake, a single lognormal distribution is expected. However, when two major phases have different uptake capacity, the overall distribution of U-L $\alpha$ intensities can only be described by superposition of multiple lognormal distributions. If the distribution function $I .(\mathrm{d} N / \mathrm{d} \log I)$ is plotted over $\log I$, the proportion can simply be calculated as the ratio of the integrals of the lognormal distributions fitted to the experimental data $(N$ is the number of pixels having U-L $\alpha$ intensity $I$ ) (see Fig. 9).

The mineralogy and structural characterisation of the areas selected was studied using a Nikon Eclipse E600 Pol polarization microscope and FEI Quanta 3D scanning electron microscope (SEM) at Eötvös University Budapest, Hungary. In order to preserve the vacuum-sensitive clay fraction for further analyses, the SEM was operated at $110 \mathrm{~Pa} \mathrm{H}_{2} \mathrm{O}$ atmosphere at low vacuum mode. Energy-dispersive $\mathrm{X}$-ray (EDX) microanalysis was performed using a $20 \mathrm{kV}$ accelerating voltage in order to excite the $\mathrm{L}_{3}$ edge of uranium. 


\section{Results and discussion}

Although several areas were measured from three thin sections prepared from each of the samples, results of two typical areas are to be discussed below in detail. These areas are representing general rock composition since they contain clayey matrix and fracture and cavity fillings as well (Fig. 4). The similarity of structures in the samples from the two sites (i.e. fracture filling surrounded with argillaceous matrix) allows us to compare the effect of mineralogical differences of the two studied blocks of BCF on their $\mathrm{UO}_{2}{ }^{2+}$ uptake.

Based on the SR micro-XRF mapping performed on the selected areas (Fig. 4), the spatial distribution of $\mathrm{U}$ in sample D-11, derived from WMA Block, is different from that of Ib-4 sample collected from Gorica Block (Fig. 5). On the sample Ib-4, where a calcite, dolomite and analcime filled fracture and clayey matrix were studied (Fig. 5), $\mathrm{U}$ distribution shows strong correlation with $\mathrm{K}$ and $\mathrm{Fe}$ as it can be seen on the scatter plot (Fig. 6). In contrast, on the sample D-11 where a K-feldspar, albite, calcite and ankerite-rimmed dolomite filled fracture and the adjacent argillaceous matrix was selected for the mapping (Fig. 4), the $\mathrm{UO}_{2}{ }^{2+}$ uptake onto the Fe- and $\mathrm{K}$ rich clayey matrix is less significant (Fig. 6), however, around the dolomite rhombohedra with ankerite rim U- and Fe-rich rings are visible (Fig. 5).
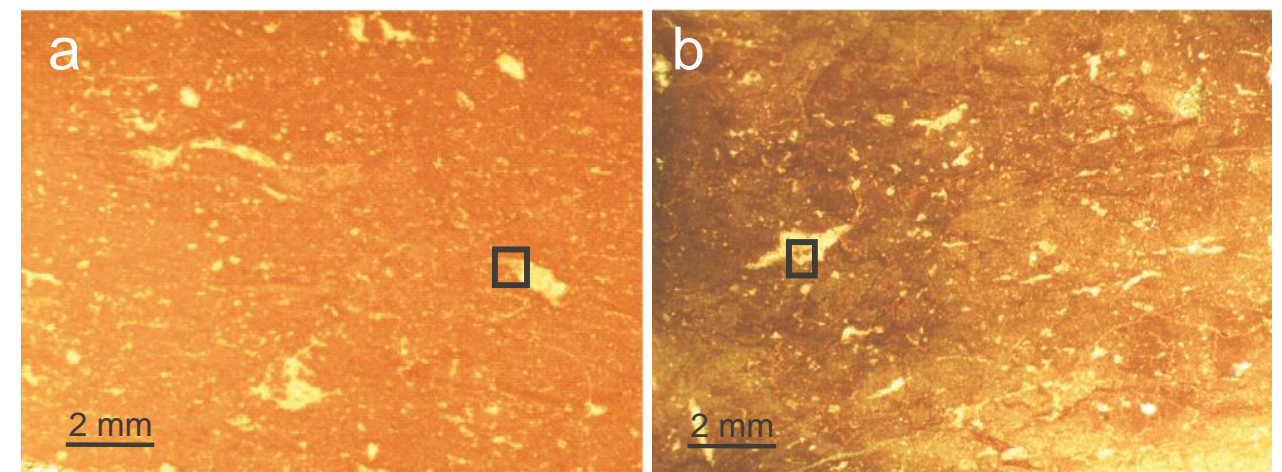

Fig. 4 Microscopic images of sample D-11 from WMA Block (a) and Ib-4 from G Block under reflected light (b). The black rectangles indicate areas of which $\mu$-XRF mapping results are discussed
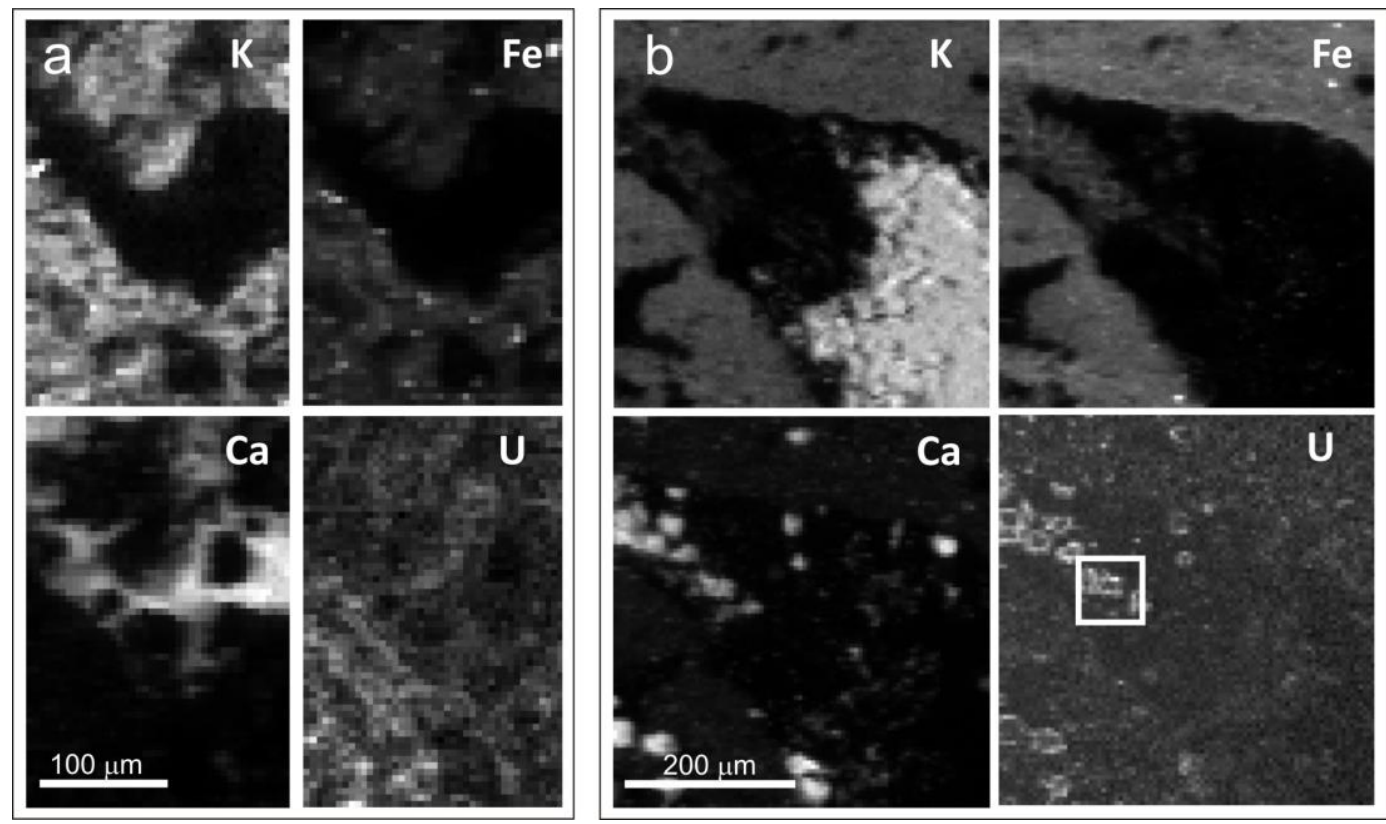

Fig. 5 SR micro-XRF maps of K. Fe, Ca and U in the areas marked by black rectangles on Fig. 4 in sample Ib-4 from G Block (a) and D-11 from WMA Block (b). The white rectangle shows the area where polarization microscopy and scanning electron microscopy was performed 

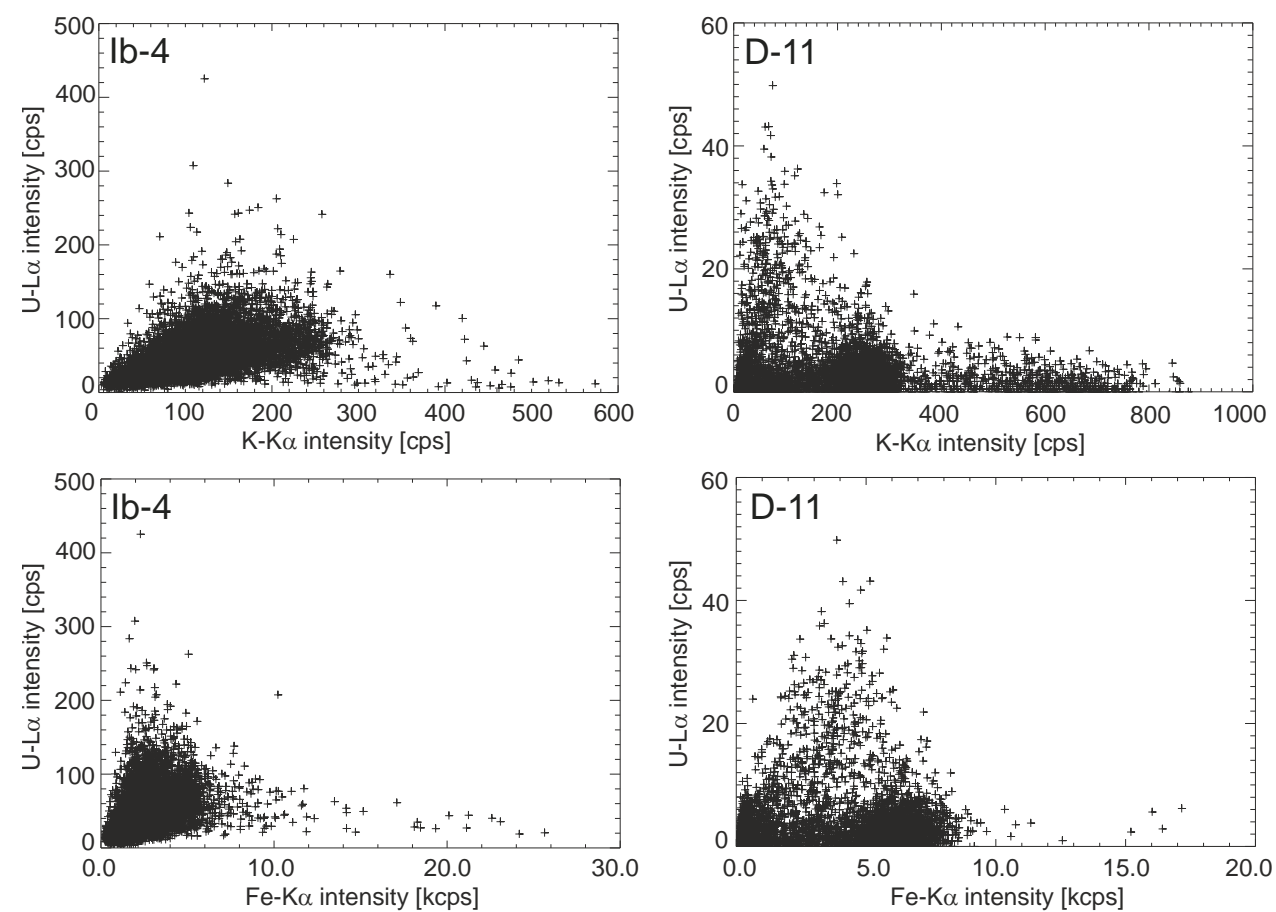

Fig. 6 Scatter plots of characteristic X-ray intensities of $U$ and $\mathrm{K}$ as well as U and Fe measured using SR microXRF on the areas selected in samples Ib-4 from G Block and in samples D-11 from WMA Block (Fig. 4 and 5)
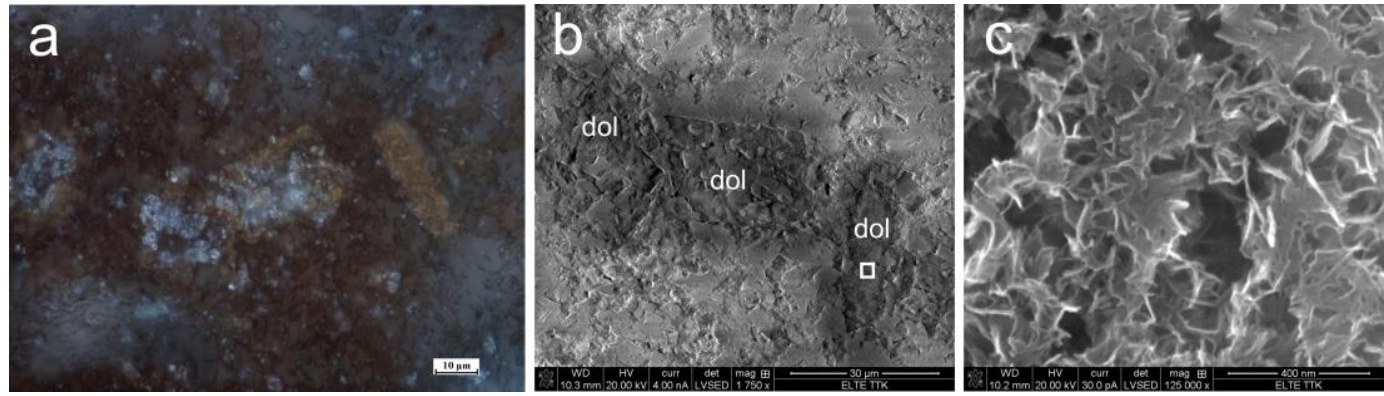

Fig. 7 Polarization microscopic (a) and secondary electron images (b, c) of zoned dolomite grains (dol) surrounded with argillaceous matrix in BCF sample D-11 from WMA Block (the images were collected from the area marked with white rectangle on Fig 5 (b), uranium elemental map). The higher magnification image (c) corresponds to the area marked with a white rectangle in (b). The reddish colour of the rim on the polarization microscopic image (a) (reflected light) indicates newly formed FeOOH minerals. Secondary electron images (b and c) show the spongy structure of the mineralization formed around and on ankerite rims of dolomite grains

In order to explain the significant differences in uptake of $\mathrm{UO}_{2}{ }^{2+}$ in the two samples investigated, detailed mineralogical study was performed by use of polarization and scanning electron microscope.

In the sample D-11 (WMA Block) where U- and Fe-rich rims were formed replacing ankerite rims, the polarization microscopic study revealed that these newly formed phases are 2-10 microns thick and have reddish colour under reflected light (Fig. 7a). On the scanning electron microscopic images it can be seen that the newly formed rim has spongy structure, which indicates formation of acicular or lensshaped precipitation (Fig. 7b). The reddish colour (Fig. 7a), the local maximum of Fe intensity (Fig. $5 b$ ), furthermore the acicular shape of the newly formed phase indicate secondary $\mathrm{FeOOH}$ formation. Similarly structured secondary FeOOH formation was described by Antunes et al. (2003) and Castaño et al. (2010) in corrosion products on steels. Since ankerite contains $\mathrm{Fe}$ as $\mathrm{Fe}^{2+}$, the formation of $\mathrm{FeOOH}$ requires oxidation of $\mathrm{Fe}$. One of the processes of $\mathrm{Fe}$ oxidation is due to reduction of $\mathrm{U}^{6+}$.

The significant role of these surface-bound $\mathrm{Fe}^{2+} \rightarrow \mathrm{Fe}^{3+} / \mathrm{U}^{6+} \rightarrow \mathrm{U}^{4+}$ redox systems for the fixing of uranium onto rock surfaces was investigated in details by Liger et al. (1999), their findings were in full correspondence with the previous work of Stumm and Sulzberger (1992). As an indirect proof of $\mathrm{Fe}^{2+}$ 
oxidation induced by $\mathrm{U}^{6+}$ reduction, the uptake experiments were repeated on fresh D-11 thin sections with structures similar to the original ones. The control experiments were carried out on the one hand at $\mathrm{pH} 8.0$, and on the other hand at $\mathrm{pH} 6.8$ but using $\mathrm{Ni}^{2+}$ instead of $\mathrm{UO}_{2}{ }^{2+}$ in the solution. After both of these experiments, no reddish coloured rims (see Fig. 7c) were observable on ankerite by optical microscopy. Thus the correlation between surface-sorbed $U$ and ankerite rims is explained by the reduction of $\mathrm{U}^{6+}$ by insoluble $\mathrm{U}^{4+}$. The suspected $\mathrm{FeOOH}$ species are attributed to the local oxidation of $\mathrm{Fe}^{2+}$ present in the ankerite. The $\mathrm{pH}$ conditions were also favourable to the solid forms of the ionic forms of both elements.

Although, in the sample Ib-4 (Gorica Block) the vug and veinlet infilling calcite and $\mathrm{Fe}^{2+}$-bearing dolomite (Fig. 8a and b) are affected by leaching as it is indicated by the corroded surface (Fig. 8c), no spongy structured rims were formed in contrast to the sample D-11.

Polarization microscopy and SEM/EDX investigations of untreated thin sections of D-11 and Ib-4 were performed in order to confirm the origin of $\mathrm{FeOOH}$, that is, whether the weathering and the formation of reddish $\mathrm{FeOOH}$ phase occurred already during rock formation or it was initiated by the sorption experiment itself. Polarization microscopy does not show the reddish colour in the position of the ankerite rims on the D-11 thin sections and no signs of weathering were observed for thin sections of both $\mathrm{D}-11$ and $\mathrm{Ib}-4$. Therefore this assessment confirmed that the weathering of ankerite and dolomite phases and the formation of the $\mathrm{FeOOH}$ minerals took place during the uptake experiment.

During the sorption experiment the $\mathrm{pH}$ shifted from 6.8 to 7.1 and 7.3 in case of sample D-11 and Ib4 , respectively, due to the solution-rock interaction. The larger increase in the latter one can be attributed to the larger surface area of the thin section. Furthermore, within this sample the slightly acidic $\mathrm{pH}$ caused weak weathering indicated by the corroded surface that was not sufficient to dissolve the veinlets infilling calcite and dolomite totally.
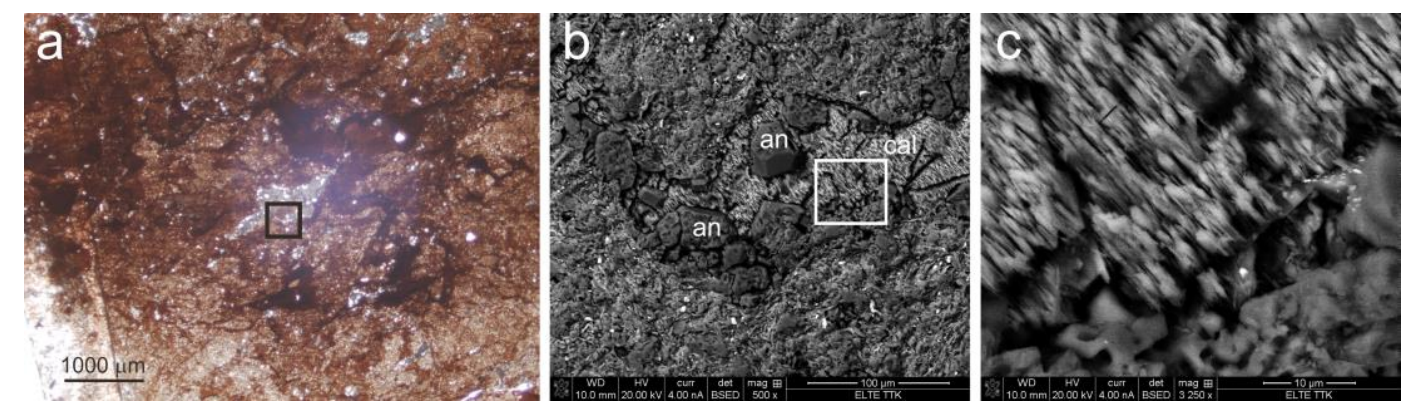

Fig. 8 Microscopic (a) and backscattered electron images (b, c) of analcime (an) and calcite (cal) filled veinlet in BCF sample Ib-4 from G Block. The electron image (b) was recorded from the area marked with black rectangle in (a). The higher magnification image (c) corresponds to the area marked with a white rectangle in (b), indicates weathering of calcite

Since the revealed U-bearing rings were formed only in sample D-11, where dolomites have ankerite rim, and these U-rings connect to the newly formed $\mathrm{FeOOH}$ phase, which replaced the ankerite, the contribution of ankerite is clear in the process.

Due to the replacement of $\mathrm{Mg}^{2+}$ with $\mathrm{Fe}^{2+}$, which caused structural distortion (Mg has a slightly larger ion radius than $\mathrm{Fe}^{2+}, 0.83$ and $0.78 \AA$, respectively) in octahedral position of carbonate structure, the solubility of ankerite is higher than that of dolomite (Rosenberg and Foit Jr 1979). Therefore, the 6.8 $\mathrm{pH}$ was acidic enough to dissolve the ankerite rims of dolomite in the sample D-11. The high $\mathrm{Fe}^{2+}$ content (ca. 20 wt. \% FeO) supports the $\mathrm{FeOOH}$ formation after ankerite dissolution. Although, in sample Ib-4 dolomites and calcites contain some $\mathrm{FeO}\left(<1\right.$ wt. \%), due to the low $\mathrm{Fe}^{2+}$ content and lower solubility of dolomite, no $\mathrm{FeOOH}$ was formed.

Although the extensive absorptive feature of clay minerals had already been revealed (Bradbury and Baeyens 2011; Joseph et al. 2011; Hartmann et al. 2008), it was found in the present study that a significant portion of the immobilized uranium is sorbed onto $\mathrm{FeOOH}$, with a percentage much higher than the chemical concentration of the sorbent. 
The proportion of the newly formed phase in uranium uptake was calculated based on the distribution of the U-L $\alpha$ X-ray intensities ( $I$ ) over the areas selected on samples D-11 and Ib-4 (Fig. 5). Since the U content can only have nonnegative value in any pixel and its expected value is small compared to the standard deviation (variation over the measured area), it should follow lognormal distribution. For this reason the measured distribution expressed as $I .(\mathrm{d} N / \mathrm{d} \log I)$ was plotted in equidistant intervals in $\log I$ (Fig. 9), where $N$ denotes the number of pixels corresponding to intensity $I$. As the uranium uptake capacity of the clayey matrix and that of the newly formed FeOOH rings is different, the measured distribution can only be described using two lognormal distributions with different parameters. The two lognormal distributions used for the fit represent the uptake by the clayey matrix (peaking at $\log I$ $=0.475$ ) and by the U-rich rings (peaking at $\log I=1.089$; see Fig. 9a). The contribution of the U-rich rings in the total $U$ content of the selected area was calculated using the integral of the fitted distributions. Based on the calculations, the newly formed $\mathrm{FeOOH}$ phase is responsible for $25 \%$ of the total $\mathrm{UO}_{2}{ }^{2+}$ uptake, whereas the clayey matrix is responsible for the remaining $75 \%$. For sample $\mathrm{Ib}-4$, the distribution of the U-L $\alpha$ X-ray intensities over the selected area could be described using a single lognormal distribution, indicating that mostly the clayey matrix is responsible for the uptake (Fig. 9b). As introduced above, the probable explanation for the observed iron- and uranium-rich rings, replacing ankerite, is the redox reaction followed by uranium precipitation. Similar findings were published by Krawczyk-Bärsch et al. (2004) who pointed out that $\mathrm{UO}_{2}{ }^{2+}$ preferably adsorbs on chlorites which have higher $\mathrm{Fe}$ content and hence secondary $\mathrm{Fe}$-oxyhydroxides were formed. These $\mathrm{FeOOH}$ particles provided additional surface area and additional surface binding sites for $\mathrm{UO}_{2}{ }^{2+}$ complexation (Krawczyk-Bärsch et al. 2004), which is a common mechanism described by others in soils and rocks (e.g. Koons et al. 1980; De Putter et al. 1999; Arnold et al. 2001). Zheng et al. (2003) concluded that ferrihydrite-like complexes have even larger importance in $\mathrm{UO}_{2}{ }^{2+}$ uptake than clay minerals in soil systems.

\section{Concluding remarks}

The information on uptake is essential to understand the behaviour of uranium, which can be released by dissolution from HLW and to identify the differences between the two candidate geological sites in their uptake capacity for the precise site selection. Such an extensive and detailed study on BCF has not been performed so far.

The observed U-bearing rings formed only in sample from WMA Block (sample D-11), where dolomites have ankerite rim and these U-rings connect to the newly formed $\mathrm{FeOOH}$, which replaced the ankerite as a result of surface oxidation. Although in G Block (sample Ib-4) dolomites are not zoned, they have some minor $\mathrm{Fe}^{2+}$ content. However, this amount of $\mathrm{Fe}^{2+}$ was insufficient to form new mineral phases during the sorption experiment. Around the dolomites, which have ankerite rim the dissolution of ankerite is followed by $\mathrm{FeOOH}$ formation resulted from oxidation of $\mathrm{Fe}^{2+}$ by $\mathrm{U}^{6+}$ reduction, which phase easily binds uranium due to the process described above. Furthermore, this effect is also enhanced by the increase of the specific surface area. As a result about $25 \%$ of the total bound $\mathrm{U}$ was present in this form on the sample from the BCF in WMA Block.

The above-mentioned difference in mineralogy could influence significantly the $U$ retention capacity of the BCF in the two studied blocks in conditions of a hypothetical release scenario from a radioactive waste repository, when dissolved $\mathrm{UO}_{2}{ }^{2+}$ can interact with the rock.

The weathering of ankerite and the formation of $\mathrm{FeOOH}$ phases using a slightly acidic $\mathrm{pH}$ during sorption experiments pointed out that the appropriate design of experimental conditions is very important in order to model the sorption when the rock-pore water system is in equilibrium. 

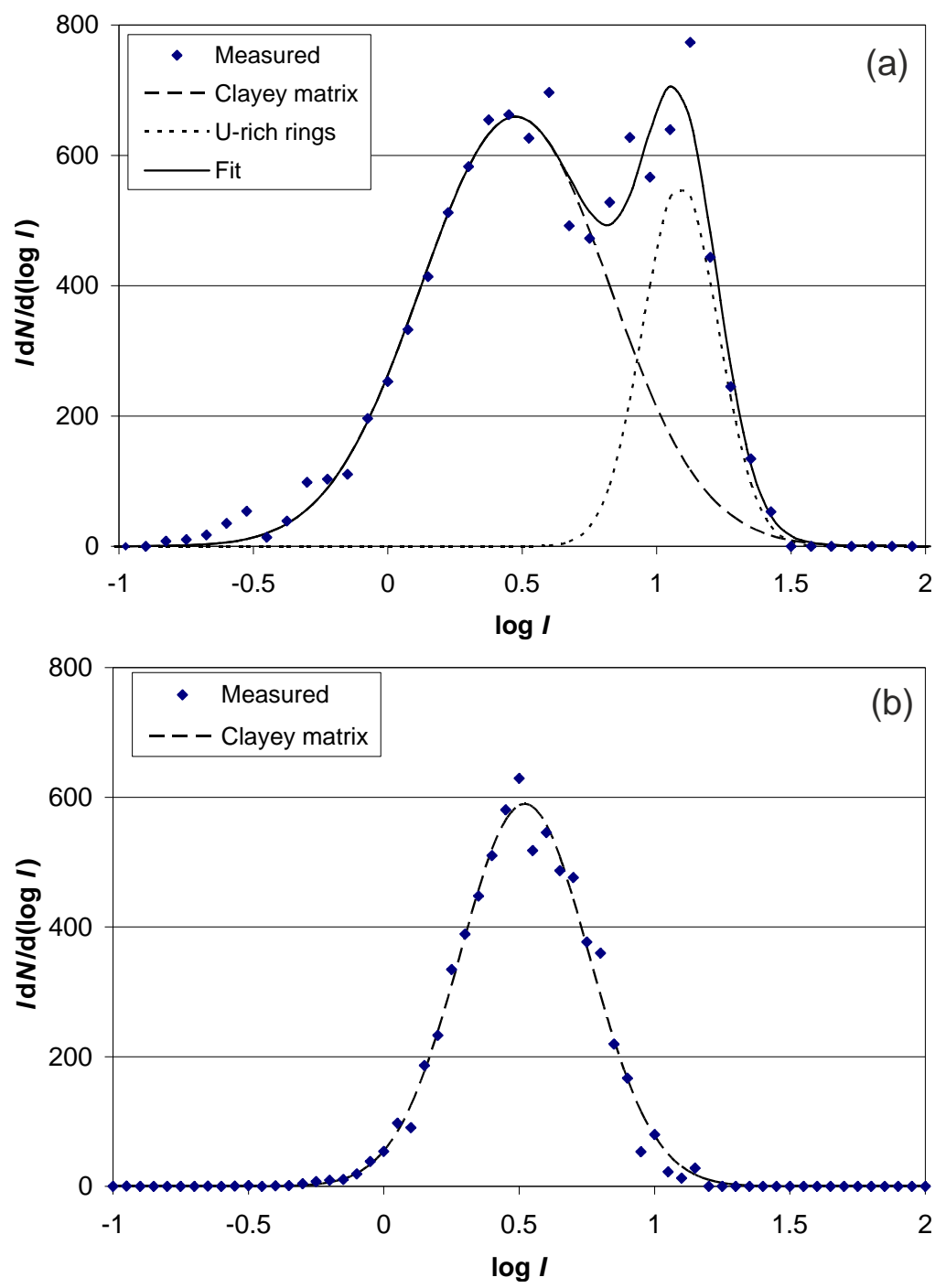

Fig. 9 Distribution of U-L $\alpha$ X-ray intensities $(I)$ on the areas selected in the samples D-11 from WMA Block (a) and Ib-4 from G Block (b), plotted as a distribution function ( $I d N / d \log I)$ in equidistant intervals in $\log$ I. For sample D-11, two lognormal distributions were fitted to the measured points representing the clayey matrix and the U-rich rings, resulting in a $25 \%$ contribution of U-rich rings in the total U content of the selected area shown in Fig. 5b. For sample Ib-4, a single lognormal distribution could be fitted indicating the exclusive role of the clayey matrix in the U uptake.

\section{Acknowledgements}

The research leading to these results has received funding from the Swiss-Hungarian Cooperation Programme through Project ${ }^{\circ} \mathrm{SH} / 7 / 2 / 11$ and from the European Community's Seventh Framework Programme (FP7/2007-2013) under grant agreement $n^{\circ} 226716$.

We acknowledge the Synchrotron Light Source ANKA for provision of instruments at their beamlines and we would like to thank Rolf Simon for assistance in using beamline FLUO and Ábel Szabó for his great help in sample preparation.

The courtesy of the Public Limited Company for Radioactive Waste Management (PURAM, Hungary) for providing the samples for analysis is also appreciated.

\section{References}

Andersson J, Skagius K, Winberg A, Lindborg T, Ström A (2013) Site-descriptive modelling for a final repository for spent nuclear fuel in Sweden. Environ Earth Sci 69:1045-1060

Antunes AR, Costa I, de Faria ALD (2003) Characterization of corrosion products formed on steel in the first month of atmospheric exposure. Mat Res 6:403-408. 
Árkai P, Balogh K, Demény A, Fórizs I, Nagy G, Máthé Z (2000) Composition, diagenetic and postdiagenetic alterations of a possible radioactive waste repository site: the Boda Albitic Claystone Formation, southern Hungary. Acta Geol Hung 43:351-378.

Arnold T, Zorn T, Zänker H, Bernhard G, Nitsche H (2001) Sorption behaviour of U(VI) on phyllite: experiments and modeling. J Cont Hydr 47:219-231.

Bachmaf S, Merkel BJ (2011) Sorption of uranium(VI) at the clay mineral-water interface. Environ Earth Sci 63:925-934.

Barabás A, Barabás-Stuhl Á (1998) Stratigraphy of the Permian formations int he Mecsek Mountains and its surroundings. In: Stratigraphy of geological formations of Hungary. Mol Plc. and Hung. Geol. Institute, Budapest, pp 187-215. [in Hungarian]

Boisson JY (2005) Clay Club Catalogue of Characteristics of Argillaceous Rocks, Radioactive Waste Management, OECD Nuclear Energy Agency, ISBN 92-64-01067-X Bradbury MH, Baeyens B (2009) Sorption modelling on illite. Part II: Actinide sorption and linear free energy relationships. Geochim Cosmochim Acta 73:1004-1013.

Bradbury MH, Baeyens B (2011) Predictive sorption modeling of Ni(II), Co(II), Eu(III), Th(IV) and U(VI) on MX-80 bentonite and Opalinus Clay: A "bottom-up" approach. Appl Clay Sci. 52:27-33.

Castaño JG, Botero CA, Restrepo AH, Agudelo EA, Correa E, Echeverría F (2010) Atmospheric corrosion of carbon steel in Columbia. Corr Sci 52:216-223.

Denecke MA, Janssens K, Proost K, Rothe J, Noseck U (2005). Confocal micrometer-scale X-ray fluorescence and X-ray absorption fine structure studies of uranium speciation in a tertiary sediment from a waste disposal natural analogue site. Environ Sci Technol 39:2049-2058

De Putter T, Charlet JM, Quinif Y (1999) REE, Y and U concentration at the fluid-iron oxide interface in late Cenozoic cryptodolines from Southern Belgium. Chem Geol 153:139-150.

Fröhlich RD, Amayri S, Drebert J, Grolimund D, Huth J, Kaplan U, Krause J, Reich T (2012) Speciation of $\mathrm{Np}(\mathrm{V})$ uptake by Opalinus Clay using synchrotron microbeam techniques. Annal Bioanal Chem 404:2151-2162.

Gaona X, Kulik DA, Mace N, Wieland E (2012) Aqueous-solid solution thermodynamic model of U(VI) uptake in C-S-H phases. Appl Geochem 27:81-95.

Green-Pedersen H, Pind N (2000) Preparation, characterization, and sorption properties for Ni(II) of iron oxyhydroxide-montmorillonite. Coll Surf A 168:133-145.

Guczi J, Szabó Gy (1995) A stroncium és cézium szorpciójának vizsgálata a Bodai Aleurolit Formációból származó kőzeten - részjelentés. Nemzeti Projekt a Nagyaktivitású Radioaktív Hulladékok Mélységi Elhelyézésére. OSSKI, p. 19.

Guczi J, Szabó Gy (1996) A stroncium és cézium szorpciójának vizsgálata a Bodai Aleurolit Formációból származó kőzeten - zárójelentés. Nemzeti Projekt a Nagyaktivitású Radioaktív Hulladékok Mélységi Elhelyézésére. OSSKI, p. 39.

Guczi J, Szabó Gy (1997) Urán szorpciójának vizsgálata a Bodai Aleurolit Formációból származó kőzeten - részjelentés. A Magyarországi Nagyaktivitású és Hosszú Élettartamú Radioaktív Hulladékok Megoldására Irányuló Célprogram. OSSKI, p. 27.

Hartmann E, Geckeis H, Rabung T, Lützenkirchen J, Fanghänel T (2008) Sorption of radionuclides onto natural clay rocks. Radiochim Acta 96:699-707.

Jámbor Á (1964) Lower Permian formations of the Mecsek Mountains. Manuscript, Mecsek Ore Environment Company, Pécs [in Hungarian]

Joseph C, Schmeide K, Sachs S, Brendler V, Geipel G, Bernhard G (2011) Sorption of uranium(VI) onto Opalinus Clay in the absence and presence of humic acid in Opalinus Clay pore water. Chem Geol 284:240-250.

Konrád Gy, Sebe K, Halász A, Babinszki E (2010) Sedimentology of a Permian playa lake: the Boda Claystone Formation, Hungary. Geologos 16:27-41.

Koons RD, Helmke PA, Jackson ML (1980) Association of trace elements with iron oxides during rock weathering. Soil Sci Soc Am J 44:150-59.

Krawczyk-Bärsch E, Arnold T, Reuther H, Brandt F, Bosbach D, Bernhard G (2004) Formation of secondary Fe-oxyhydroxide phases during the dissolution of chlorite - effects on uranium sorption. Appl Geochem 19:1403-1412. 
Lázár K, Máthé Z (2012) Claystone as a potetial host rock for nuclear waste storage. In: Valaškova M, Martynkova GS (eds) Clay minerals in Nature - Their Characterization, Modification and Application. ISBN 978-953-51-0738-5; DOI: 10.5772/48123

Liger E, Charlet L, Van Cappellen P (1999) Surface catalysis of uranium(VI) reduction by iron(II). Geochim Cosmochim Acta 63:2939-2955.

Máthé Z (ed) (1998) Summary report of the site charachterization program of the Boda Siltstone Formation, Vol. 4. Manuscript, Mecsek Ore Environment Company, Pécs, 76 p.

Máthé Z, Varga A (2012) „Seasoning” to the palaeoenvironmental reconstruction of the Permian Boda claystone Formation: pseudomorphs after halit in the claystone samples of the deep drillings BAT4. Bull Hung Geol Soc 142:201-204.

Meleshyn A, Azeroual M, Reeck T, Houben G, Riebe B, Bunnenberg C (2009) Influence of (calciumuranyl-carbonate complexation on U(VI) sorption on Ca and Na-bentonites. Environ Sci Technol 43:4896-4901.

Mell P, Megyeri J, Riess L, Máthé Z, Hámos G, Lázár K (2006a) Diffusion of Sr, Cs, Co and I in argillaceous rock as study by radiotracers. J Radioanal Nucl Chem 268:411-417.

Mell P, Megyeri J, Riess L, Máthé Z, Csicsák J, Lázár K (2006b) Sorption of Co, Cs, Sr and I onto argillaceous rock as studied by radiotracers. J Radioanal Nucl Chem 268:405-410.

Nair S, Karimzadeh L, Merkel BJ (2014) Surface complexation modeling of Uranium(VI) sorption on quartz in the presence and absence of alkaline earth metals. Environ Earth Sci 71:1737-1745.

Németh T (2011) Deatiled mineralogical study of samples of Boda Siltstone Formation (BSF). Project report, Hungarian Academy of Sciences Institute for Geochemical Research, Budapest, Hungary, p. 35.

Rosenberg EP, Foit Jr FF (1979) The stability of transition metal dolomites in carbonate systems: a discussion. Geochim Cosmochim Acta 43:951-955.

Schwartz MO (2009) Modelling groundwater contamination above the Asse 2 medium-level nuclear waste repository, Germany. Environ Earth Sci 59:277-286.

Sipos P, Németh T, Máthé Z (2010) Preliminary results ont he Co, Sr, and Cs sorption properties of the analcime-containing rock type of the Boda Siltstone Formation. Central European Geology 53:67-78.

Stumm W, Sulzberger B (1992) The cycling of iron in natural environments: Considerations based on laboratory studies of heterogeneous redox processes. Geochim Cosmochim Acta 56:3233-3257.

Szabó Gy, Guczi J, Bálint M, Valyon J (2004) Radiostrincium, radiocézium, radiocarbon, radiojód, urán, americium, tórium és plutonium szorpciós folyamatainak vizsgálata a felszínközeli mállott BAF-mintákon a minta környezetére jellemző ionösszetételű folyadékmintákból. - jelentés. OSSKI, p. 43.

Varga A, Szakmány Gy, Raucsik B, Máthé Z (2005) Chemical composition, provenance and early diagenetic processes of playa lake deposits from the Boda Siltstone Formation (Upper Permian), SW Hungary. Acta Geol Hung 48:49-68.

Varga A, Raucsik B, Szakmány Gy, Máthé, Z (2006) Mineralogical, petrological and geochemical characteristics of the siliciclastic rock types of Boda Siltstone Formation. Bull Hung Geol Soc 136:201-232.

Vekemans B, Janssens K, Vincze L, Adams F, Van Espen P (1994) Analysis of X-ray spectra by iterative least squares (AXIL): new developments. X-Ray Spectrom 23:278-285.

Wieland E, Mace N, Dähn R, Kunz D, Tits J (2010) Macro- and micro-scale studies on U(VI) immobilization in hardened cement paste. J Radioanal Nucl Chem 286:793-800.

Zheng Z, Tokunaga KT, Wan J (2003) Influence of calcium carbonate on U(VI) sorption to soils. Environ Sci Technol 37:5603-5608. 